\title{
連鋳製高炭素鋼線材の伸線加工性におよぼす 中心偏析の影響

\section{Effect of Central Segregation on Drawability of High-carbon Steel Wire Rod Manufactured from Continuously Cast Blooms}

Ikuo OCHIAI, Hiroshi OHBA, Yohji HidA and Michihiko Nagumo

\begin{abstract}
Synopsis :
A study has been made on the microstructure of the central segregation zone in wire rod and its fracture process for the purpose of improving the drawability by reducing central segregation in high-carbon steel wire rod manufactured from continuously cast blooms. (1) In the central segregation zone of wire rod, a kind of duplex segregation which consists of segregation plateau and microsegregation peaks was observed. This type of segregation is considered to originate from the macrosegregation in cast blooms. (2) The fracture which occurred during wire drawing was initiated from the martensite stringers or proeutectoid cementite networks on the microsegregation peaks formed on the segregation plateau. The propagation of fracture was governed by the width of the segregation plateau. (3) A dominant factor governing wire drawability is the width of the segregation plateau, that is, the width of the macrosegregation spots in cast blooms.
\end{abstract}

Key words : high-carbon steel ; wire rod ; segregation ; continuous casting ; drawing ; wire ; fracture.

\section{1. 緒}

\section{言}

炭素を 0.70 〜 $0.85 \%$ 含有する高炭素鋼線材は, 熱処 理 (パテンティング) 後高隇面率の伸線加工を施され, $\mathrm{PC}$ 鋼線, 吊橋用ケーブル，ばね，スチールコードなど に代表される高強度鋼線の製造に供されている．高炭素 鋼線材に要求される特性のうち, 強度とならぶ重要な特 性は伸線加工性であり，その低下は伸線中の断線あるい は伸線後の鋼線の延性不足, すなわち, 絞り值や捻回值 の低下を惹起する. 伸線加工性を支配する治金的要因と しては，鋼組成，非金属介在物，パーライトのラメラ間 隔などがあげられるが, 最近の趨勢ともいえる鋼線の高 強度化にともない中心偏析の占める比重が増大しつつあ る.

連続鋳造法で製造された高炭素鋼線材の中心偏析に関 する従来の研究は, 鋳片やビレットのドリル分析, 線材 のマクロエッチングやサルファプリント, 硬さ分布の測
定など，ほとんどマク口的な方法にもとづいてなされ， その目的とするところは線材品質の評価という実用的な ものであつた。このため, 鋳造条件と線材のマク口偏析

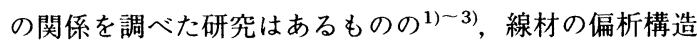
を鋳片までさかのぼつて偏析生成機構の面からとらえた 研究は見あたらず，したがつて，論理的な偏析改善技術 を構築することは不可能であつた.

本研究は，連鋳製高炭素鋼線材における偏析低減化指 針の明確化を目的として，はじめに，ブルーム連鋳製高 炭素鋼のビレットおよび線材の中心偏析のミクロ構造を 解析し，それらと伸線加工性の関係を明らかにした。次 いで，その結果にもとづいて，伸線加工時の中心偏析帯 における破壊の進行過程を考察し, 高炭素䤡線材の伸線 加工性を支配する偏析要因は偏析度や偏析面積率ではな く, 鋳片のマクロ偏析スポットの幅であることを明らか にした.

昭和 60 年 4 月本会講演大会にて発表 昭和 62 年 9 月 3 日受付 (Received Sep. 3, 1987)

* 新日本製鉄(株)君津技術研究部 工博 (Kimitsu R \& D Lab., Nippon Steel Corp., 1 Kimitsu Kimitsu 299-11)

*2 新日本製鉄(株)君津技術研究部 (Kimitsu R \& D Lab., Nippon Steel Corp.)

*3 新日本製鉄(株)君津技術研究部（現：(株)日鉄マイクロメタル）(Kimitsu R \& D Lab., Now Nippon Micrometal Corp.)

*4 新日本製鉄(株)君津技術研究部（現：早稲田大学）理博 (Kimitsu R \& D Lab., Now Waseda University) 


\section{2. 実 験方 法}

\section{$2 \cdot 1$ 供試銅}

供試鋼は JIS 規格の SWRH 72A, SWRS 77B，およ び SWRS 82B である. それらの代表的な取鍋分析值を Table 1 に示す。試料は新日本製鉄(株)君津製鉄所の実 生産設備を用いて以下の工程で製造した。供試鋼を 250 $\mathrm{t}$ 転炉で溶製後, 曲率半径 $10.5 \mathrm{~m}$ の湾曲型連鋳機を用 いて $300 \mathrm{~mm} \times 500 \mathrm{~mm}$ 断面のブルームに鋳造した。鋳 造後, 約 $650^{\circ} \mathrm{C}$ に冷却された鋳片をウォーキングビー ム型加熱炉に装入して $1300^{\circ} \mathrm{C} に$ 昇温後，ただちに分 塊圧延を開始し， $117 \mathrm{~mm}$ 角断面のビレットとした．線 材圧延はビレットを $1100^{\circ} \mathrm{C}$ に加熱後, 直径 $5.5 \mathrm{~mm}$ お よび $10.5 \mathrm{~mm}$ に圧延した. 線材圧延後, ステルモア (Stelmor) 冷却設備を用いて直接パテンティングを行つ た.この場合, 巻取温度は $850^{\circ} \mathrm{C}$, 巻取り後 $500^{\circ} \mathrm{C}$ ま での平均冷却速度汁 $5.5 \mathrm{~mm}$ 線材で䄪 $12^{\circ} \mathrm{C} / \mathrm{s}, 10.5 \mathrm{~mm}$ 線材で約 $4^{\circ} \mathrm{C} / \mathrm{s}$ とした。

\section{$2 \cdot 2$ 中心偏析}

鋳片の偏析は鋳造方向に沿つて長さ $500 \mathrm{~mm}$ の縦断面 試片を切り出し，エッチプリント法")により調榃した。

ビレットの偏析調查は横断面中心より直径 $10 \mathrm{~mm} の$ ドリルでサンプリングした試料を分析するマクロ的な方 法と，横断面より中心偏析部を含む $24 \mathrm{~mm} \times 48 \mathrm{~mm} の$ 試片を切り出し，その全面をマクロアナライザー5)を用 いて分析するミクロ的な方法により行つた（1画素は $60 \mu \mathrm{m} \times 60 \mu \mathrm{m})$.

線材の偏析については，5\%+イタール液によるマク

Table 1. Chemical composition of steels studied ( wt \%).

\begin{tabular}{c|cccccc}
\hline Steels & C & Si & Mn & P & S & Al \\
\hline SWRH 72 A & 0.72 & 0.20 & 0.50 & 0.015 & 0.005 & 0.001 \\
SWRS 77 B & 0.77 & 0.25 & 0.76 & 0.014 & 0.005 & 0.027 \\
SWRS 82 B & 0.82 & 0.25 & 0.76 & 0.014 & 0.004 & 0.025 \\
\hline
\end{tabular}

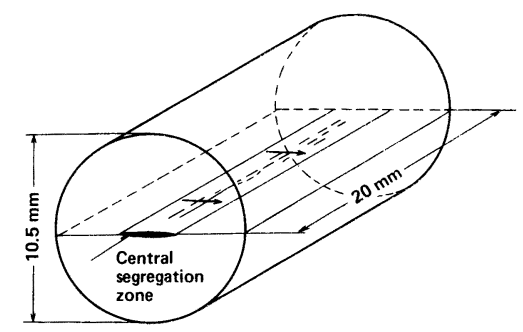

Fig. 1. Schematic representation of EPMA scanning for measuring central segregation in wire rod.
ロエッチングで中心偏析带を現出し，Fig. 1 に示すよ うに, 中心偏析带を含む被検面上を 1 画素 $2 \mu \mathrm{m} \times 2 \mu \mathrm{m}$ の二次元 EPMA (CMA) ${ }^{4)}$ で分析したのち，通常の EPMA を用いて直径方向に線分析を行つた。 ビーム径 は $2 \mu \mathrm{m}$ で 1 回の走査距離は中心部 $1 \mathrm{~mm}$ とした。試片 数は各水準 4 個, 各被検面を $10 \mathrm{~mm}$ 間隔で 2 か所測定 した.

サンプリング後の鋳片を圧延しビレットおよび線材を 製造したが，それぞれのサンプリングに際しては，鋳片， ビレット，および線材の試料が相互に隣接した位置とな るよう特に注意をはらつた。ここで，ビレットおよび線 材のサンプリング位置を鋳片上で示すと，鋳片のサンプ リング位置より，それぞれ $12.8 \mathrm{~mm}$ および $13.0 \mathrm{~mm}$ 離 れた位置に対応する。

\section{$2 \cdot 3$ 伸線加工性}

線材 $(5.5 \mathrm{~mm})$ の偏析測定位置に隣接した箇所より $11.2 \mathrm{~kg}$ (長さ $60 \mathrm{~m}$ ) の伸線用サンプルを採取し, これ を伸線試験に供した。伸線試験は線材の伸線加工性を相 対的に比較するために，材料中心軸近傍，すなわち，中 心偏析帯に作用する静水圧引張応力成分を通常の伸線条 件より大きくとつて行つた6).すなわち，1パスあたり の減面率は約 $20 \%$, ダイス半角は $15^{\circ}$ とした。なお, 伸線機は単頭式で伸線速度は $60 \mathrm{~m} / \mathrm{min}$ とした。 以上の 条件で断線するまで伸線し，（1)式より伸線限界ひずみ を求めた。

$$
\varepsilon_{f d}=\ln \left(d_{o} / d_{f}\right)^{2}
$$

ここで， $\varepsilon_{f d}$ は伸線限界ひずみ， $d_{o}$ は線材の直径， $d_{f}$ は 断線の発生したパスの入口側の鋼線直径を示す.

\section{3. 実 験 結 果}

\section{$3 \cdot 1$ 中心偏析帯のミクロ的な構造}

\section{$3 \cdot 1 \cdot 1$ 線材}

線材の中心偏析带における偏析元素の二次元的な分布 を CMA を用いて調査した. 結果の一例として, Fig. 2 の SWRS 77B (10.5 mm) の中心偏析带における Mn 分 布を示す。このように，中心偏析带においては $\mathrm{Mn}$ お よび $\mathrm{P} は$ 線材の压延方向に延伸した幅の狭い濃化領域 (以下，偏析ピークと呼び，その高さは偏析元素の濃度 を表すこととする)を多数形成している.これら偏析ピー クのプロフィルを EPMA を用いて調べると，Fig. 3 に 示すように, C, Mn，およびPはほほ同時に偏析してい ることがわかる. Mnの偏析ピークの中には著しく高い ものがあるが，光学顕微鏡で観察すると，その部分には 細長く延伸した $\mathrm{MnS}$ がみとめられた。この場合, $\mathrm{MnS}$ 


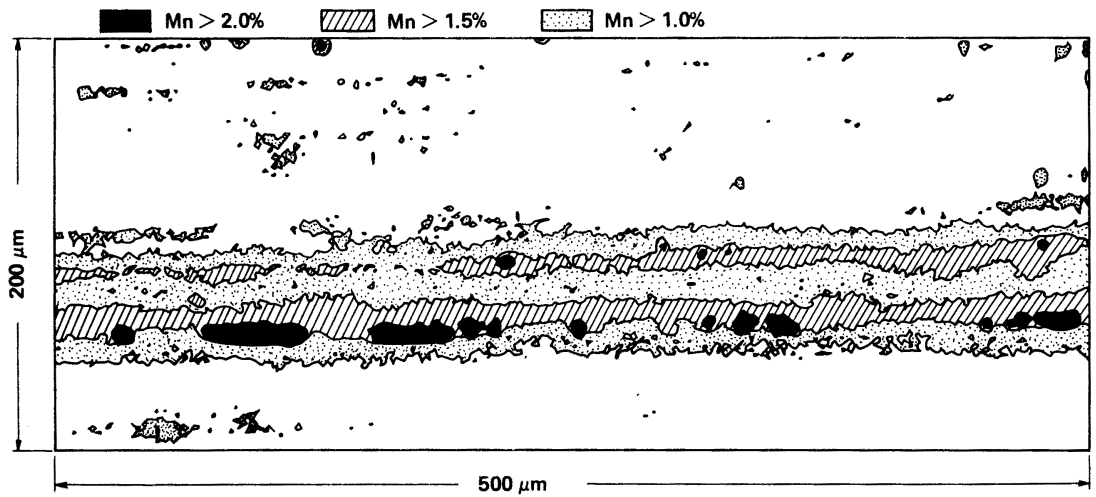

Fig. 2. Concentration mapping of manganese segregation in wire rod (SWRS77B, $10.5 \mathrm{~mm}$, longitudinal section).

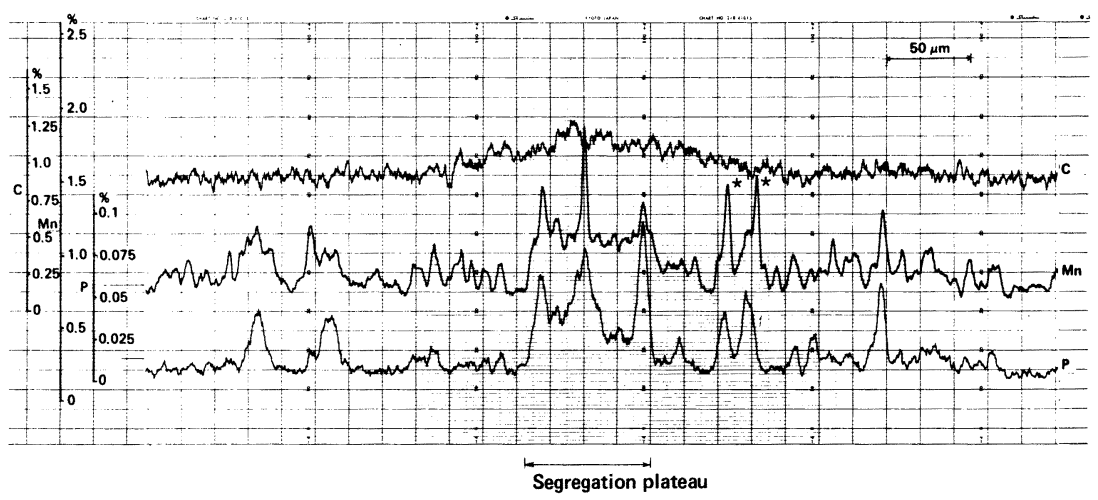

Fig. 3. Concentration profiles for carbon, manganese, and phosphorus in central segregation zone of wire rod (SWRS77B, $\left.10.5 \mathrm{~mm} .{ }^{*} \mathrm{MnS}\right)$.

の幅はほとんどが $2 \mu \mathrm{m}$ 以下であり，偏析ピークの幅に くらべてかなり小さい. なお, 酸素含有量が少なく, $\mathrm{Mn} / \mathrm{S}$ 比の高い高炭素鋼線材においては, 偏析部に存在 する $\mathrm{MnS}$ は高い冷間塑性変形能を有する ${ }^{7)}$ ため, 伸線 加工性にはほとんど影響をおよぼさないと考えられる。 したがつて, 本報告では $\mathrm{S}$ 偏析は考虑に入れないことと する。

Fig. 3 において注目す心゙きことは, MnやPの偏析 ピークには二つのタイプが存在することである.すなわ ち, 取鍋分析値に近い組成レベルを基盤とする偏析ピー ク（タイプI）と幅の広い台地状の偏析（以下，台地状 偏析という) の上に存在する偏析ピーク (タイプII ) で ある. 一方, Cの偏析プロフィルは $\mathrm{Mn}$ やPのそれと は異なり, 拡散の結果としてタイプIIの偏析ピークは消 滅し，台地状偏析も“肩”のくずれたなだらかな形とな つている. 台地状偏析の高さはその幅に依存し, 大型
化するにともなつて偏析度の増加する傾向がみとめられ た。

$$
3 \cdot 1 \cdot 2 \text { ビレット }
$$

SWRH 72A のビレットの中心偏析部における Mn 分 布をマクロアナライザーを用いて調査した. Photo. 1 はビレット横断面の中心偏析部における $0.70 \%$ (偏析 度 $=1.4$ ）以上の $\mathrm{Mn}$ の存在分布を示す. Photo. 1a に 示した集中型の偏析パターンでは大型の偏析スポットが 中心部に集中し,それらの周囲は負偏析状を呈している. これに対して, Photo. 1bのような分散型の偏析パター ンでは偏析スポットは細かく, かつ,一様に分布してい る.このようにマクロアナライザーで測定した場合, 偏 析パターンには明らかな相違が認められるが, ドリル分 析（ドリル径 $10 \mathrm{~mm}$ ) では, $\mathrm{Mn}$ 偏析度は $\mathrm{a}$ が $1.06, \mathrm{~b}$ が 1.05 と両者の差は小さい. マクロアナライザーによ り測定した各偏析スポットを円に拉き換え, 最大のもの 

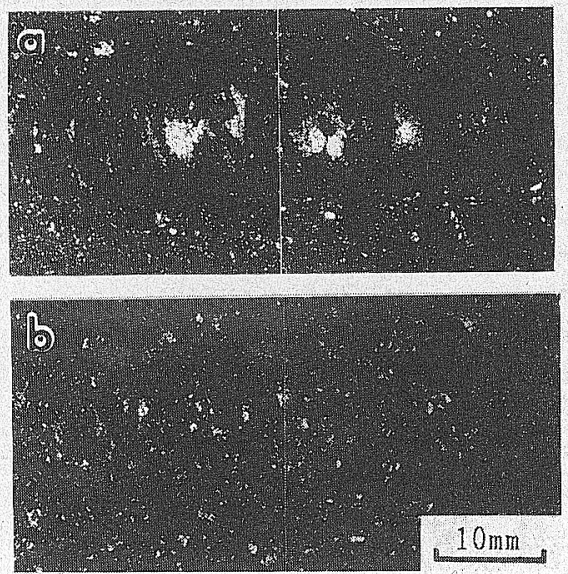

a : Concentrated pattern b : Dispersed pattern

Photo. 1. Concentration mappings of manganese segregation in billet (SWRH72A, transverse section. $\mathrm{Mn} \geqq 0.70 \%$ ).

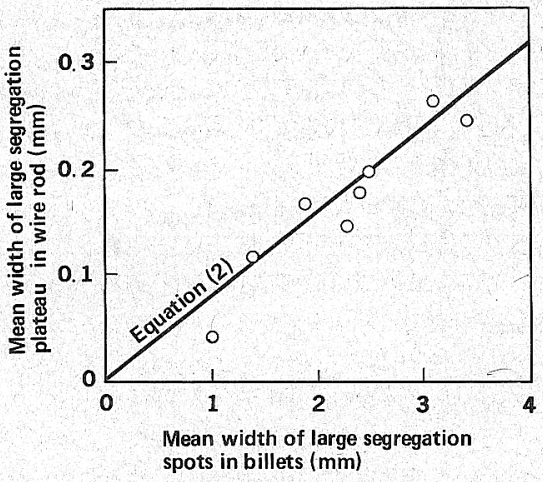

Steel : SWRH72A

Fig. 4. Relationship between mean width of large segregation spots in billets $(117 \mathrm{~mm} \times 117 \mathrm{~mm})$ and mean width of large segregation plateau in wire rod (10.5 mm).

から第 5 番めまでの平均直径をビレットの平均粗大偏析 幅，また，線材の台地状偏析の幅の最大のものから第 5 番めまでの平均值を平均粗大台地状偏析幅と定義し, 両 者の関係を調へたた。 その結果, Fig. 4 に示すように, 両者の関係は線材圧延に抢ける材料の塑性変形にもとづ いて計算された $(2)$ 式の関係にほぼ一致する.

$$
\bar{w}_{2}=\frac{b}{a} \sqrt{\frac{\pi}{4}} \cdot \bar{w}_{1}
$$

ここで, $\bar{w}_{2}$ は線材の平均粗大台地状偏析幅, $\bar{w}_{1}$ はビレッ トの平均粗大偏析幅, $b$ は線材直径, $a$ はビレットの一 辺の長さを示す.

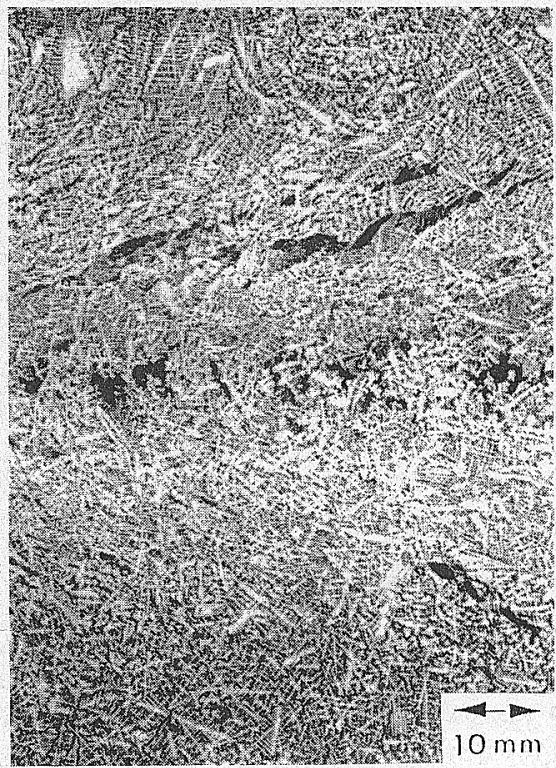

Photo. 2. Solidification structure at the central part of bloom (SWRS82B, longitudinal section).

以上の結果より, Photo. 1 に示したビレットの偏析 パターンを構成する偏析スポットのうち，大型の偏析ス ポットは線材の台地状偏析に対応することが明らかとな つた. 一方，これら偏析スポットはその大きさや分布状 態から推定して, Photo. 2 に示す鋳片のマクロ偏析, すなわち，中心偏析やV 偏析に対応すると考えられる. したがつて，線材の台地状偏析は，鋳片のマクロ偏析が 分塊ならびに線材圧延という高減面率の加工により延伸 して形成されたもの，また，そのプロフィルは鋳片のマ ク口偏析の構造上の特徽を示していると考えられる.

\section{$3 \cdot 2$ 中心偏析と伸線加工性の関係}

$3 \cdot 2 \cdot 1$ 中心偏析度および中心偏析面積率と伸線限界 ひずみの関係

SWRH 72A について伸線限界ひずみと Mn およびP の中心偏析度の関係を調査した. その結果，ビレットの ドリルサンプルによるマクロ的な偏析度および線材の EPMA 分析によるミク口的な偏析度（偏析ピーク高さ） のいずれをとつても，偏析度と伸線限界ひずみの間には 相関はみとめられなかつた。また,マクロアナライザー で測定した $0.70 \%$ 以上の Mn 偏析部がビレット横断面 中心部 $24 \mathrm{~mm} \times 48 \mathrm{~mm}$ に占める面積率を中心偏析面積 率と定義し，中心偏析面積率と伸線限界ひずみの関係を 調査したが，両者の間には相関はみとめられなかつた。 
$3 \cdot 2 \cdot 2$ ビレットの平均粗大偏析幅と伸線限界ひずみ の関係

前項 $3 \cdot 2 \cdot 1$ と同じビレットについて, $3 \cdot 1 \cdot 2$ で述べた 方法で平均粗大偏析幅を測定し，これと伸線限界ひずみ の関係を求めた．結果を Fig. 5 に示す。両者の間には 明瞭な相関がみとめられ, 平均粗大偏析幅の減少にとも ない伸線加工性は向上する。 すなわち, 集中型の偏析パ ターンに比ベて分散型の偏析パターンの方が高い伸線加 工性を示す。

$3 \cdot 2 \cdot 3$ 鋳片のマクロ偏析幅と伸線限界ひずみの関係

鋳片縦断面のエッチプリントをとり，それよりマクロ 偏析の幅を測定した．測定にあたつては，マクロ偏析の 鋳片長手方向のばらつきを考慮に入れ，平均的なマクロ 偏析を評価すべく, 長手方向 $250 \mathrm{~mm}$ (ビレット圧延に 供する鋳片側）以内に存在するマクロ偏析の幅を測定し た. 次に, その最大のものから数えて 5 番めまでの平均 值を鋳片の平均粗大マク口偏析幅と定義した.SWRS

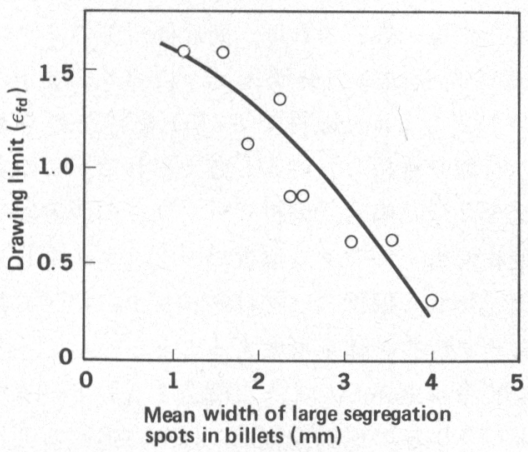

Fig. 5. Relationship between mean width of large segregation spots in billets and drawing limit (SWRH72A).

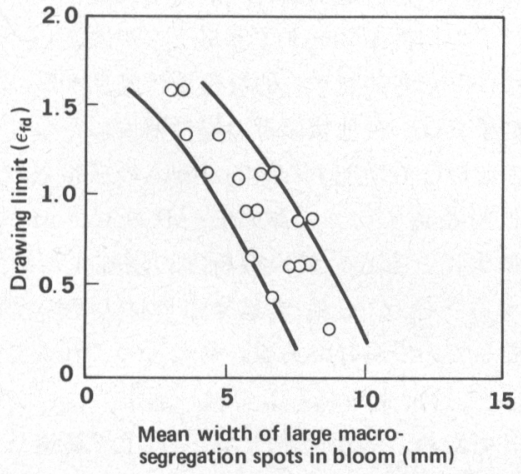

Fig. 6. Relationship between mean width of large macrosegregation spots in bloom $(300 \mathrm{~mm} \times 500 \mathrm{~mm})$ and drawing limit (SWRS82B).
82Bについて, 鋳片の平均粗大マクロ偏析幅と伸線限 界ひずみの関係を求めた．結果をFig. 6 に示す.ビレッ トの場合と同様, 両者の間には強い相関があり, 平均粗 大マクロ偏析幅の減少にともない伸線加工性は向上す る.

Fig. 6 の関係は鋳片における偏析許容限界を示すも ので，実用的な意義を有する．

$3 \cdot 2 \cdot 4$ 中心偏析带における破壊の発生

高炭素鋼線材における $\mathrm{C}$ およ゙ $\mathrm{Mn}$ 偏析部分は, そ の周囲に比べて硬質化してはいるものの, 微細パーライ 卜組織であるため十分な延性を有し ${ }^{8)}$ ，伸線にともなう ミクロクラックの発生はみとめられなかつた。 しかし,
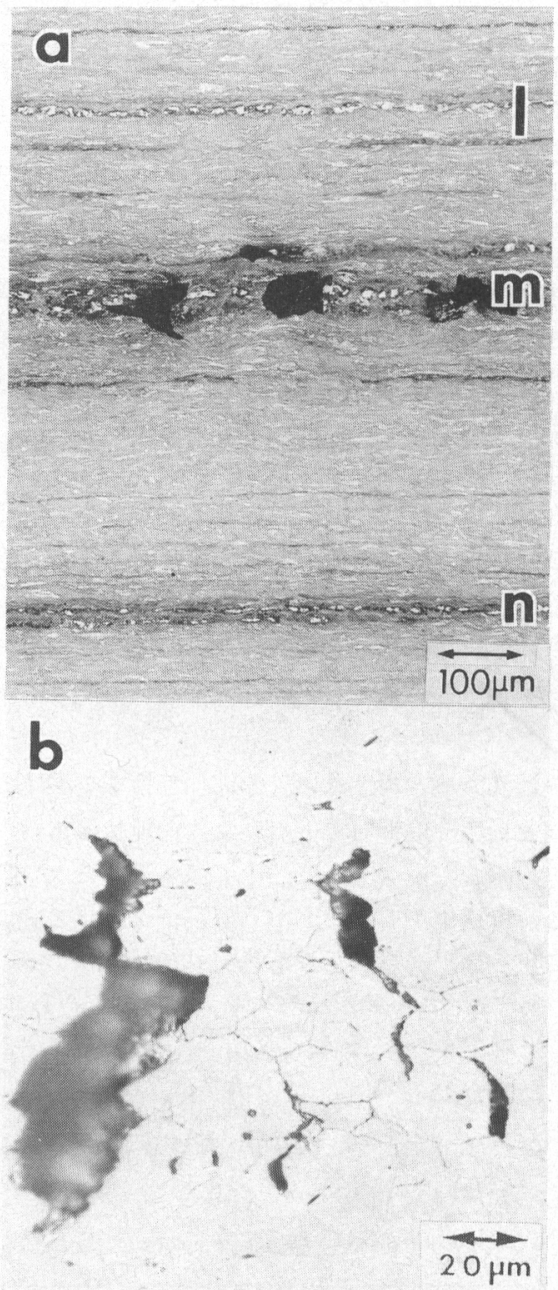

Photo. 3. Internal fracture of drawn wires caused by (a) martensite (SWRS77B), and (b) proeutectoid cementite (SWRS82B). 
Photo. 3 の断線部のミクロ組織が示すように, Mn 偏析 によりマルテンサイトが生成した場合や C 偏析により オーステナイト粒界に初析セメンタイトが析出した場合 には偏析部は破壊の起点となる（P偏析により Fe-P 化合物 ${ }^{9)}$ が生成した場合にも破壊の核になると考えられ る).

一一力, 偏析ピーク高さがマルテンサイトや初析セメン タイトの生成する臨界濃度 $\left(C_{\text {crit. }}\right)$ を越え, ピーク上に これら脆化組織が生成した場合でも，それが臨界サイズ $\left(\lambda_{\text {crit. }}\right)$ 以下であれば，伸線中，マトリックスとの間の 整合性が保たれるためにクラックは生じない. マルテン サイトについては, Photo. 3a の偏析带 l, m, n 上に生 成したマルテンサイト粒 (白色) を観察した結果, 幅 5 $\mu \mathrm{m}$ 米満のミクロマルテンサイトは小型の非金属介在物 と同様，破壊の核とはならないことがわかつた。これよ り，マルテンサイトの $\lambda_{\text {crit. }}$ は約 $5 \mu \mathrm{m}$ と考えられる. 同様に, Photo. $3 \mathrm{~b} よ り$ 初析セメンタイトの $\lambda_{\text {crit. }}$ を求 めると約 $4 \mu \mathrm{m}$ となる.

$3 \cdot 2 \cdot 5$ 中心偏析帯における破壊の伝播

Photo. 3aに扔いて, 白色のマルテンサイトに隣接す る黒色部はパーライト中にベイナイトの混在する領域, すなわち, Mn の台地状偏析の存在を示している. 黒色 部の幅は $\mathrm{m}$ が最大で, $\mathrm{n}, \mathrm{l}$ の順に小型化している.ここ で注目すべきことは， $\lambda_{\text {crit. }}$ 以上のすべてのマルテンサ イトの周井にクラックないしはボイドが発生しているに もかかわらず, 成長してマク口的な破壊を生ぜしめてい るものは, 幅の大きい台地状偏析 $\mathrm{m}$ 上のミクロクラック に限られていることである.

\section{4. 考察}

春験絬果で述べたように，伸線加工性を支配する偏析 要因は偏析度や偏析面積率ではなく台地状偏析（マクロ 偏析）の幅である。そこで, 中心偏析帯のミク口構造に 関する解析結果をもとに, 中心偏析带における破壊の伝 播過程について考察してみることとする.

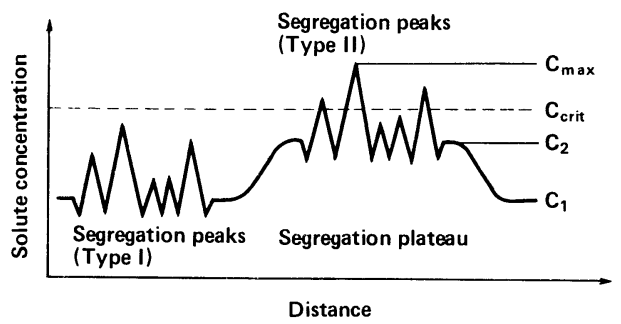

Fig. 7. Schematic diagram of central segregation zone in wire rod.
高炭素線材の中心偏析帯の特徵は, 台地状偏析上に偏 析ピークの乗つた二重構造の偏析が存在することであ る. 同様な構造の偏析はV偏析帯においてもみとめられ る.これを模式的に表したものが Fig. 7 である.ここ で, $C_{1}$ は台地状偏析周辺の濃度, $C_{2}$ は台地状偏析の高 さ， $C_{\text {max }}$ は偏析ピーク高さの最大值である。また, $C_{\text {crit. }}$ は破壊の核となる組織, すなわち, マルテンサイ トや初析セメンタイトを生成する偏析元素の臨界濃度 で, 線材のパテンティング条件に依存する.

高炭素鋼線材がこのような偏析構造をとる理由は, 台 地状偏析が鋳片のマクロ偏析に対応するという実験結果 にもとづいて説明することができる. すなわち, 凝固末 期において，デンドライト樹間の濃化溶鋼の流動により 中心偏析や V 偏析が形成されると考えると ${ }^{10)}$, 比較的 広い濃化溶鋼のプールの中から初晶が晶出するため, 幅 が広く, かつ, 周用より濃度の高い「台地」と, その上 に立つ「ピーク」(ミクロ偏析ピーク) が形成され, 線 材で観察されるところの二重構造の偏析プロフィルにな ると考えられる．換言すれば，鋳片偏析部のミクロ的な 偏析構造は高減面率の熱間圧延（たとえば, $10.5 \mathrm{~mm}$ 線材で $1732,5.5 \mathrm{~mm}$ 線材で 6313$)$ を経たのちも，な お，その特徴を維持していると考えられる。このような 偏析構造をとつた場合, 偏析ピーク高さの最大值は必然 的に台地状偏析上のミクロ偏析ピーク（タイプ II ）に存 在し, タイプII の偏析ピークはタイプIに比べて背の高 い偏析ピークの集合体を形成することとなる.

中心偏析帯は上述したような構造を有しているため, そこにおける破壊の伝播過程は，以下に述べるように， $C_{\text {crit. }}$ のレベルと台地状偏析の幅により異なつた様相を 呈す.

( 1 ) $C_{\text {crit. }}<C_{2}$ の場合

この場合には, 台地状偏析に沿つて大型のマルテンサ イトバンドや初析セメンタイトゾーンが生成し, ミクロ 的な破壊はただちにマク口的な破壊に成長する.

春験結果では, 台地状偏析の幅の増大にともない, そ れ自身の偏析度も増加する傾向がみとめられたが,これ は，厚板用連鋳スラブにおいて，Pおよび $\mathrm{Mn} の$ 偏析 粒径の増大にともない最大偏析度の増加する傾(向 ${ }^{11) 12)}$ と一致する. $C_{2}$ が $C_{\text {crit. }}$ を越えるのは大型の台地状偏 析が生成している場合である. 著者らのこれまでの研究 によれば ${ }^{13)}, \mathrm{Mn}$ 偏析に関しては, 通常, $C_{2}$ と $C_{\text {crit. }}$ の 差が大きいため, 溶鋼過熱度 $35^{\circ} \mathrm{C}$ 以上で鋳造した場合 などを除けば， $C_{2}$ が $C_{\text {crit. }}$ を越えることはない．これ に対して，C偏析に関しては， $C_{\text {crit. }}$ が低いため，0.75\% 以上の C を含む高炭素鋼では $C_{2}$ が $C_{\text {crit. }}$ を越える場合 


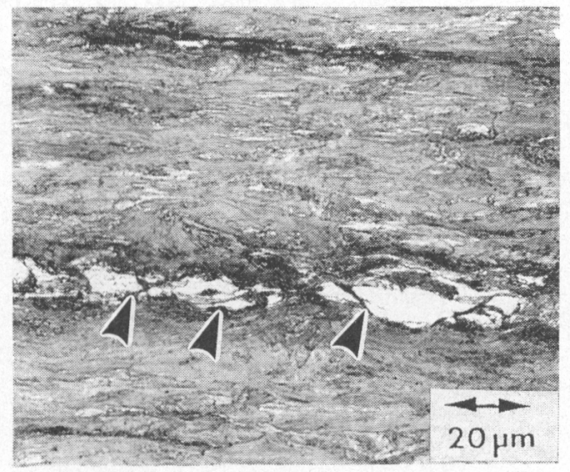

Photo. 4. Martensite formed on segregation zone "l" in Photo. 3a. Arrows indicate microcracks formed at martensite/pearlite boundaries.

が少なくない.

( 2 ) $C_{2}<C_{\text {crit. }}<C_{\text {max. }}$ の場合

この場合は, マルテンサイトなどの脆化組織は何条か の狭幅の帯として存在する. 帯の相互の間隔は, タイプ IIの偏析の成因から理解されるように狭い。このような 脆化組織の「束」のある部分で発生したミクロ的な破壊 が成長してマク口的な破壊に至るか否かは「束」の大き さ，すなわち，台地状偏析の幅に依存している. Photo. 3a で台地状偏析 $\mathrm{m}$ は幅が最大で， $\lambda_{\text {crit. }}$, すなわち, 5 $\mu \mathrm{m}$ 以上の幅を有するマルテンサイトの帯が 4 条みとめ られる.これに対して，台地状偏析 $\mathrm{n}$ および $\mathrm{l}$ は小型で あり， $\lambda_{\text {criL }}$ 以上の幅を有するマルテンサイトの帯は 1 ないし 2 条である. 偏析带 1 上に生成したマルテンサイ トを Photo. 4 に示す. $\lambda_{\text {crit. }}$ 以上の幅を有するすべての マルテンサイトの带は破壊の核を形成しているが，破壊 の伝播の様相は台地状偏析の幅によつて著しく異なつて いる.すなわち， mにおいてはマルテンサイトを起点と する破壊は, 同一の台地状偏析上に隣接して存在する他 のミクロ偏析ピーク上のマルテンサイトと合体をくりか えしてマクロ的な破壊に至つている. これに対して, n や】においては, マルテンサイトの带が小さいために, そこに形成されたクラックはマクロ的な破壊に成長する ことはない。これより，中心偏析带における破壊の伝播 を支配する偏析要因は， $C_{\text {crit. }}$ を越えるタイプ II の偏析 ピーク群の大きさ，すなわち，台地状偏析の幅であると 考えられる。

ミクロ偏析上にクラックが発生してもマクロ的な破壊 に成長しえない台地状偏析の臨界幅を $w_{\text {crit. }}$ とすると, $w_{\text {crit. }}$ はダイス通過時の材料内応力分布に加えて，破壊 の伝播に対するマトリックスの感受性，すなわち，パテ
ンティング条件によつてきまるパーライト構造，あるい は伸線加工ひずみなどに依存する。また， P偏析に関し て言えば，たとえ $\mathrm{P}$ 偏析ピーク高さが $C_{\text {crit. }}$ 以下であつ ても, P偏析部のフェライトは固溶強化が大きく, かつ, 破壊の伝播に対する感受性が強いために $w_{\text {crit. }}$ を小さく する効果があると考えられる。

( 3 ) $C_{\text {max. }}<C_{\text {crit. }}$ の場合

中心偏析帯に脆化組織が生成しないため, マトリック スの組織に応じた高い伸線加工性が得られる。

一方，偏析ピークの存在は鋼線断面内の不均質性と異 方性を助長するため, 伸線減面率や鋼線強度が著しく高 い場合には, 鋼線の延性, 特に捻回特性への影響を考慮 する必要があると考えられるが, これは今後の課題であ る.

\section{5. 結}

言

連鋳製高炭素鋼線材の偏析低減化指針を明確にするこ とを目的に, 線材の中心偏析帯のミクロ構造の解析およ びその伸線加工性への影響を調査し，伸線加工時の中心 偏析帯における破壊の進行過程について考察した.

(1) 線材の中心偏析帯には, 台地状偏析上にミクロ偏 析ピークが乗つた二重構造の偏析がみとめられる.これ は, 鋳片のマクロ偏析, すなわち, 中心偏析やV 偏析が 熱間压延で延伸することにより形成されたと考えられ る.

( 2 )伸線加工時, 中心偏析帯における破壊の起点は台 地状偏析上のミクロ偏析ピークに沿つて生成したマルテ ンサイトや初析セメンタイトである.これらミクロ偏析 上の脆化組織を起点とする破壊は, 同一の台地状偏析上 の隣接して存在する他のミクロ偏析上の破壊と合体をく りかえしながらマクロ的な破壊に成長する.したがつて, 破壊の伝播を支配する要因は偏析ピーク群の大きさ，す なわち, 台地状偏析の幅である.

( 3 )伸線加工性を支配する偏析要因は, 偏析度や偏析 面積率ではなく, 台地状偏析の幅, すなわち, 鋳片のマ クロ偏析の幅である。

\section{文献}

1) M. KaWamoto, $K$. Yamada and T. Fujita: Wire J., 10 (1977) 7 , p. 94

2 ) K. Theis and M. KLemn: Wire J., 15 (1982) 1, p. 66

3 ) M. Baraux and G. Mangel: Wire J., 17 (1984) 4, p. 66

4 ）宮村 紘, 田口 勇, 曾我 弘: 鉄と鋼, 69 (1983), A 197

5 ) 北村公一, 川島捷宏, 曽我 弘, 小川洋之, 佐伯 毅, 佐藤光義，金子治郎: 鉄と鋼，70 (1984), p. 2294

6 ) 田中 浩, 佐藤 優, 吉田一也: 塑性加工学会春季講演会 (1981), p. 517 
7 ) L. Luyckx, T. R. Bell, A. Melean and M. KoRnChynSKI: Metall. Trans., 1 (1970), p. 3341

8 ) T. Takahashi, M. Nagumo and Y. Asano: Wire J., 13 (1980) 11 , p. 78

9 ）黑澤文夫, 田口 勇: 鉄と鋼, 71 (1985), A45

10) $H$. Mori, $N$. Tanaka, $N$. Sato and $M$. Hirai: Trans. Iron Steel Inst. Jpn., 12 (1972), p. 102
11）土田 裕, 中田正之, 菅原功夫, 宮原 忍, 村上勝彦, 田口喜代美: 鉄と鋼，69（1983），A209

12）北岡英就，藤村俊生，野崎 努，垣生泰弘: 鉄と鋼, 69 (1983), A 201

13）落合征雄, 大羽 浩, 飛田洋史, 南雲道彦: 未発表 